\title{
Causas de Obstrução Nasal na Infância
}

\author{
Raimar Weber ${ }^{1}$
}

\section{Resumo}

O artigo tem o objetivo de recordar as diversas causas de obstrução nasal na faixa etária pediátrica.

Palavras chave: obstrução nasal; cavidade nasal; crianças

Weber, Raimar. "Causas de Obstrução Nasal na Infância", in Anais do 2o. Congresso Internacional Sabará de Especialidades Pediátricas

\footnotetext{
${ }^{1}$ Médico Otorrinolaringologista do Hospital Infantil Sabará. Doutor em Otorrinolaringologia pela Faculdade de Medicina da USP. E-mail: raimar@doctor.com
} 


\section{Introdução}

A respiração bucal na criança não deve ser considerada uma alternativa fisiológica, e sim uma condição patológica. As diversas consequências da respiração bucal na infância - alterações craniofaciais, de oclusão dentária, nutricionais, cardiopulmonares, além de distúrbios do sono, desempenho escolar e de qualidade de vida - serão abordadas em capítulo à parte. O presente artigo tem o objetivo de revisar as causas de obstrução nasal na infância.

\section{Avaliação da criança com obstrução nasal: a endoscopia nasal e os exames radiológicos}

A endoscopia nasal é um exame relativamente simples, que consiste na visualização das cavidades nasais e nasofaringe (podendo estender-se até a visualização da hipofaringe e laringe) utilizando-se de um sistema de fibra óptica e fonte de luz, podendo ou não ser acoplado a um sistema de vídeo. Presenças de desvios septais, tumores, pólipos, sinusites, hipertrofias de tonsila faríngea (adenóides), hipertrofias de cornetos (ou conchas) nasais inferiores, atresias coanais dentre outras causas de obstrução nasal podem ser confirmados pela endoscopia nasal sem expor a criança à radiação. Cada vez mais a endoscopia nasal é considerada parte do exame físico otorrinolaringológico frente às queixas nasais.

A endoscopia nasal pode ser realizada desde o período neonatal. O diâmetro dos nasofibroscópios flexíveis mais finos é de cerca de 2,8 mm, sendo que os mais amplamente utilizados na prática otorrinolaringológica estão entre 3,7 a 4,1 mm. Pode ser realizada em consultório na própria consulta otorrinolaringológica, sob anestesia tópica. A instilação prévia de um anestésico tópico, como lidocaína 2\% associada a vasoconstritor tópico como a oximetazolina a 0,025\%, promovem anestesia e vasoconstrição satisfatórias da mucosa nasal, facilitando a visualização das estruturas nasais e nasofaríngeas, e tornando o exame perfeitamente tolerável para a criança, exigindo mínima contensão.

Embora indispensável em determinados casos, a indicação de exames radiológicos em crianças deve ser ponderada. O aumento da exposição de crianças à radiação está associado a maior risco do desenvolvimento de neoplasias posteriormente. Enquanto radiografias simples utilizam relativamente baixos níveis de radiação, tomografias computadorizadas podem expor as crianças a doses até 200 vezes maiores de radiação que a de um raio-X simples de tórax. Situações em que as tomografias computadorizadas de nariz e seios paranasais são indispensáveis, incluem a suspeita de tumores nasossinusais, malformações, cistos dermóides e meningoceles/meningoencefaloceles.

\section{Causas de Obstrução Nasal no período Neonatal}


Embora a grande maioria das obstruções nasais no período neonatal sejam transitórias e benignas, a obstrução nasal nesse período pode tornar-se um quadro dramático, gerando grande ansiedade aos pais. Recém nascidos são respiradores nasais exclusivos, e esta condição se mantém até aproximadamente 2 a 5 meses de vida.

A endoscopia nasal está indicada sempre que a obstrução no neonato for persistente ou intensa. Exames de imagem, como a tomografia computadorizada e a ressonância magnética devem ser realizados sempre que se visualizarem à inspeção - seja a olho nu ou com auxílio de endoscópios - de massas, assimetrias ou rinorréia mucóide/purulenta persistentes, para a avaliação definitiva da suspeita de malformações, meningoceles/meningoencefaloceles, cistos dermóides e ou outros tumores.

A obstrução nasal secundária a medicamentos utilizados pela gestante é uma condição benigna e transitória, devendo ter conduta expectante. Esses medicamentos incluem anti-hipertensivos, como a metildopa, reserpina, hidralazina e guanetidina, antidepressivos, narcóticos e beta-bloqueadores.

Embora não seja frequente, a contaminação nasal ocorrida durante o canal de parto deve ser lembrada em todo recém-nascido com obstrução nasal acompanhada de rinorréia purulenta. Exame de bacterioscopia, cultura e antibiograma da secreção deve ser realizado. Em geral, as rinites purulentas de início precoce têm como etiologia estreptococos, clamídia e gonococos. Rinites purulentas de início tardio estarão mais associadas a estafilococos, transmitidos através da amamentação.

Desvios do septo nasal são muito frequentemente vistos ao nascimento, sendo mais frequentes nos nascidos via parto vaginal quando comparados com os por cesárea. A maior parte dos desvios da porção cartilaginosa anterior do septo nasal corrigem-se espontaneamente dentro dos primeiros 30 dias de vida.

A atresia de coana ocorre aproximadamente a cada 8.000 nascimentos, é 5 vezes mais comum no sexo feminino, e a forma mais comum é a unilateral. Enquanto a forma unilateral pode passar despercebida por meses (ou até anos) até ter seu diagnóstico, a forma bilateral, consiste em urgência respiratória logo ao nascimento, lembrando que o recém-nascido é respirador nasal exclusivo. O manejo inicial pode ser bem sucedido com a utilização de sondas de Guedel, porém o definitivo é cirúrgico.

\section{Causas de Obstrução Nasal no período Pós-Neonatal}

Os cornetos nasais (ou conchas nasais) inferiores são indubitavelmente os principais responsáveis pela obstrução nasal não apenas em crianças, mas também em adultos. Acredita-se que a principal função das conchas nasais inferiores sejam esquentar e umidificar o ar quando esse passa em um fluxo laminar em íntimo contato com sua mucosa. A inflamação secundária a rinites (sejam de etiologia alérgica ou mesmo provocadas por mecanismos irritativos) e sinusites, no entanto, leva a edema das conchas nasais, gerando obstrução transitória da passagem do ar. O estímulo inflamatório crônico, por sua vez, pode levar a degeneração e hipertrofia da mucosa da concha nasal, levando a obstrução permanente. O tratamento clínico da rinite, incluindo desde a lavagem frequente do nariz com soro fisiológico até o uso de corticóide tópico nasal, anti-histamínicos e 
outros medicamentos via oral, pode e deve ser realizado pelo pediatra e outros médicos não otorrinolaringologistas com o objetivo de desobstruir o nariz da criança através do controle da inflamação da mucosa nasal. Toda criança que persistir com obstrução nasal apesar de controle adequado de rinites e sinusites, deve ser avaliada pelo especialista otorrinolaringologista, que pode considerar a redução cirúrgica do volume dos cornetos nasais.

A adenóide, ou tonsila faríngea, é formada por tecido linfóide, fazendo parte do sistema imune. Está estrategicamente localizada na rinofaringe, estando exposta a antígenos tanto alimentares como inalatórios. Desempenha papel importante na apresentação de antígenos, especialmente nos primeiros anos de vida. Sua retirada quando necessário, porém, demonstra não comprometer o funcionamento do sistema imune, uma vez que o tecido linfático presente em inúmeros outros lugares do organismo desempenha o mesmo papel da adenóide. Esses locais incluem o sistema MALT - nódulos linfáticos difundidos ao longo das mucosas e submucosas de todo tubo digestivo (faringe, esôfago, estômago es principalmente intestinos) e da árvore respiratória (desde no nariz, traquéia e brônquios) - os linfonodos e o baço. Os estímulos que levam ao crescimento (hiperplasia) do tecido linfóide presente na adenóide incluem a resposta a infecções (virais ou bacterianas), alergias alimentares ou a inalantes, e irritantes ambientais ou alimentares. A retirada da adenóide estará indicada quando estiver provocando obstrução da passagem do ar na rinofaringe, além de situações como infecções locais crônicas ou recorrentes (otites e sinusites).

Desvios do septo nasal podem provocar obstrução nasal em qualquer idade. Não há tratamento clínico que leve a correção do desvio, sendo seu único tratamento o cirúrgico. Quando necessário o tratamento cirúrgico antes da adolescência, este deve ser o mais conservador possível, uma vez que a ressecção de zonas de crescimento da cartilagem septal podem interferir no crescimento da pirâmide nasal.

A presença de Pólipos na cavidade nasal podem indicar diferentes entidades clínicas, e tomografias computadorizadas sempre estarão indicadas, uma vez que podem esconder neoplasias subjascentes. Pólipos Antro-coanais (ou Pólipos de Killian), são pólipos benignos únicos que afetam principalmente crianças e adultos jovens, contando com 1/3 dos pólipos nasais nessa faixa etária. Crescem a partir do meato médio na região do antro maxilar por razões desconhecidas em direção à coana e faringe. A polipose nasossinusal, por sua vez, indica a presença de múltiplos pólipos em diferentes regiões da cavidade nasal; a presença de sinusite e polipose nasal em crianças deve levantar a suspeita diagnóstica de fibrose cística (mucoviscidose).

Corpos estranhos na cavidade nasal de crianças são queixas comuns em pronto-atendimentos pediátricos, e na maior parte das vezes são facilmente resolvidos. O problema surge quando ninguém testemunha a criança introduzir o corpo estranho no nariz ou quando a mesma não conta que o fez. Deve-se suspeitar de corpos estranhos na cavidade nasal sempre que houver surgimento repentino de obstrução nasal unilateral associado a rinorréia, principalmente se esta for de característica fétida.

\section{Conclusões}

Diversas são as causas de obstrução nasal no paciente pediátrico. O não especialista pode e deve saber manejar rinites e sinusites. A persistência de obstrução e outros sintomas nasais apesar de tratamento clínico adequado demanda a avaliação pelo especialista otorrinolaringologista

A endoscopia nasal é exame importante para o diagnóstico da(s) causa(s) de obstrução nasal, podendo ser realizado em consultório sob anestesia tópica. 
Lembrar que, na maioria dos casos, há mais de uma causa de obstrução nasal presente.

English Title: Causes of nasal obstruction in infants and children

Abstract: The article is intended to recall the various causes of nasal obstruction in pediatric patients.

Keywords: nasal obstruction, nasal cavity, infants, children 